\title{
Determinants of the offer of breast milk complements for newborns
}

Josilene Maria Ferreira Pinheiro ( $\nabla$ josilenemfp@gmail.com )

Universidade Federal do Rio Grande do Norte https://orcid.org/0000-0003-0564-4828

Taiana Brito Menêzes Flor

Universidade Federal do Rio Grande do Norte

Vanessa Cristina da Costa Pires

Universidade Federal do Rio Grande do Norte

Amanda Michelly Braga da Mata

Universidade Federal do Rio Grande do Norte

Luana Isabelly Carneiro de Oliveira

Universidade Federal do Rio Grande do Norte

Wanessa Pinheiro de Macedo Barbosa

Universidade Federal do Rio Grande do Norte

Fábia Barbosa de Andrade

Universidade Federal do Rio Grande do Norte

\section{Research article}

Keywords: Infant Nutrition, Breast Feeding, Infant Formula, Infant Nutritional Physiological Phenomena

Posted Date: October 13th, 2020

DOl: https://doi.org/10.21203/rs.3.rs-89962/v1

License: (1) (1) This work is licensed under a Creative Commons Attribution 4.0 International License. Read Full License 


\section{Abstract}

Background: Although exclusive breastfeeding is recommended in the first hours of life, it is common to offer infant formula to the newborn, resulting in a negative effect on breastfeeding. This study has the objective of identifying the prevalence of the offer of food complements, its characteristics and the determining factors.

Methods: Cross-sectional study, linked to a cohort study that assessed the newborn care in four public maternity wards in Natal. The sample was composed of 415 mothers and full-term newborns, with appropriate weight for gestational age and Apgar scores in $1^{\text {st }}$ and $5^{\text {th }}$ minutes $\geq 7$. In order to analyze the association between the socioeconomic, biological and welfare characteristics and the offer of the complement for the newborn, we used Pearson's Chi-Square, Student's t-test, and Poisson's regression.

Results: Of the 415 newborns, $51.3 \%$ received complements (57.6\% in the first hour of life), of which $92 \%$ with infant formula. Of these, only $50.7 \%$ were prescribed by the doctor. Colostrum deficiency was the main reason for indication (33.8\%). The maternal age $\leq 20$ years ( $\mathrm{PR}=0.64 ; 95 \% \mathrm{Cl}=0.47-0.86)$ and between 20 30 years $(\mathrm{PR}=0.70 ; 95 \% \mathrm{Cl}=0.57-0.87$ ) were shown as protective factors, while being primiparous ( $\mathrm{PR}=1.37$; $95 \% \mathrm{Cl}=1.11-1.60)$ and had undergone cesarean section $(\mathrm{PR}=1.2 ; 95 \% \mathrm{Cl}=1.00-1.45)$ as predictive factors.

Conclusion: We observed that maternal characteristics are determinants for the offer of complement to the newborn in the first hours of life. The high prevalence shows the need for interventions that minimize the inadequate offer of infant formula and promote exclusive breastfeeding before hospital discharge.

\section{Background}

Exclusive Breastfeeding (EB) - which should be offered from birth to the first 6 months of life - is among the World Health Organization recommendations for reducing child mortality [1-3]. Studies show that the chances of remaining in breastfeeding $(\mathrm{BF})$ in the first month and in the following months are greater when the newborn (NB) is placed in immediate contact with the genitor, skin-to-skin, and even more when it is possible to accomplish the "Golden Hour". This consists in placing NB in the maternal breast in the first hour of life [4].

In this context, the Baby-Friendly Hospital Initiative (BFHI) advocates prevalence above $80 \%$ for breastfeeding within the first hour after birth [4]. Nevertheless, studies have pointed out that such a target has not been achieved $[5,6]$. Therefore, it is fundamental to know the factors that contribute to the failure of EB. The circumstances of birth (prematurity and low weight, for example), the social determinants (age, socioeconomic level and education) and the maternal clinical conditions (breast problems - such as cracked nipples and breast ingurgitation), the cesarean delivery and the welfare aspects (absence of a companion in the delivery room, for example) appear as the determinants, commonly associated with the impediment of breastfeeding and the offer of the complement in lieu of BF during the hospitalization of the mother/child binomial [7]. 
The actions to protect and promote breastfeeding have been instituted in Brazil since the 1980s, with the National Breastfeeding Promotion Program, the installation of Human Milk Banks (HMB), Brazilian Breastfeeding and Complementary Feeding Strategy and the legislation on breast milk substitutes [8, 9]. In the following decade, BFHI was strengthened, when the implementation, the training, the follow-up, the assessment and the reassessment of the "Ten Steps to Successful Breastfeeding" were instituted. Among them, the steps 4 - "To help mothers to start breastfeeding within the first half hour after the birth of the baby" - and 6 - "Do not give the newborn baby any food or drink other than breast milk, unless such procedure has a medical indication" [4].

We should highlight that BFHI provides justified reasons for offering complementary breastfeeding - either with breast milk from the milk bank or with infant formulas - under the following conditions: extreme premature NB, very low weight, risk of hypoglycemia, innate errors of the metabolism that require a special formula; seropositive mothers, using chemotherapy and other toxic substances, mothers with hepatitis, tuberculosis and other clinical conditions that prevent breastfeeding [4].

In maternity wards, the offer of complements to EB is a frequent practice for low-risk neonates, even if they do not have justifiable reasons through BFHI, with an approximate prevalence of $75 \%$ [10], varying among countries [11-15]. In Brazil, studies show a prevalence between $16 \%$ and $63.5 \%$ in different regions [7], being associated with the intrinsic conditions to NB (immediate absence of skin-to-skin contact and breastfeeding in the first hour of life, the use of a pacifier, difficulty in latching and sucking, hypoglycemia and infection) and to the mother (age, previous experience of breastfeeding, obesity and gestational diabetes), as well as the absence of professional guidance in the prenatal and puerperium, besides the nonaccreditation of the maternity ward in BFHI are also associated with the indiscriminate offer of the complement [10, 11, 13-17].

Another worrying factor has been the increased offer of milk formulas due to the shortage of pasteurized breast milk in human milk banks (HMB). This practice, in turn, has been related to the increased risk of intestinal dysbiosis, infections and allergy to the cow's milk protein in NB $[14,18]$. It is known that breast milk is rich in essential amino acids, growth factors, immunoglobulins, probiotics, among other essential substances for neonatal development.

When considering that the indiscriminate offer of the complement is among the causes that undermine breastfeeding - substantially in the first hours and days after birth -, it is fundamental to know the factors associated with its offer. Accordingly, this study has the objective of identifying the prevalence of the use of complements to breast milk for NB, their characteristics, as well as the determining factors of this practice in public maternity wards.

\section{Methods}

\section{Study setting}

This study was held in four public maternity wards in the city of Natal, in the state of Rio Grande do Norte (northeast region of Brazil). The municipality represents a percentage of $42 \%$ of live births in the 
aforementioned state, being its largest representation in maternity wards linked to the Brazilian Unified Health System (SUS, as per its Portuguese acronym). It has 13 Primary Health Units, 41 Family Health Units, 1 Municipal Health Unit, 4 Emergency Care Units, 3 Family Health Support Center teams, 113 Family Health Strategy teams and 592 community health workers, 4 public maternity wards and 3 private maternity wards.

\section{Study design and sample}

The study is typified as cross-sectional, part of the cohort study called "Child Care in the Neonatal Period". It was conducted from February to August 2019, with the objective of assessing the health care actions recommended by the Agenda for Child Health Care, the Stork Network (RC, as per its Portuguese acronym) and the National Policy for Comprehensive Child Health Care (PNAISC, as per its Portuguese acronym) in the first 28 days of life of NB. The representative sample of the main study considered a prevalence of $70 \%$ in the performance of the actions, with $\mathrm{OR}=1.2$, a confidence level of $95 \%$, a power of study and an estimate of non-response of $20 \%$. In total, 415 mothers were interviewed in the four maternity wards, proportionally distributed according to the number of live births in 2018.

\section{Instrument and data collection}

After stratification of the sample, data collection was performed daily, for 1 to 2 months in each maternity ward, totaling a period of 7 months from the beginning to the end of the collection. Initially, in the maternity ward, the medical records were consulted to identify the newborns that met the following eligibility criteria: full-term live births ( $\geq 37$ weeks), birth weight $\geq 2,500 \mathrm{~g}$, Apgar score in $1^{\text {st }}$ and $5^{\text {th }}$ minutes $\geq 7$ and single pregnancy. The inclusion criteria were not met by mothers who were not in good health conditions to respond to the research instrument. The interview with the mother took place through a questionnaire tested in a pilot study and applied by a team of previously trained researchers. For this study, some variables (actions) collected in the first follow-up interview were used, which was performed 48 hours after delivery. When the information was not written in the medical record, it was collected directly from the mother.

\section{Variables}

The main analyzed outcome was the offer of a complement to the maternal milk during the hospitalization of NB until the moment of the interview. The complement is characterized by the offer to the pasteurized maternal milk or infant formula in the absence of the first one, under different conditions. The prescriptions, indications, type, volume and time of the offer were also assessed.

The independent explanatory variables, characterized as possible determinants for the offer of the complement in a rooming-in setting were those related to the maternal individual characteristics (age, education, income, parity, clinical condition of diabetes, type of delivery), the characteristics and clinical condition of NB (gender, weight at birth and glycemic values before the offer of the complement); the welfare variables (companion during the delivery process, skin-to-skin contact and breastfeeding in the first hour of life) and the institutional variables (administrative nature of the maternity ward, level of complexity, "Baby-Friendly" degree through BFHI and number of professionals per bed). 


\section{Statistical analysis}

The statistical analysis of the data was performed through the SPSS ${ }^{8}$ Statistical Program, version 20.0. The association between independent and dependent variables was made by means of Pearson's ChiSquare test, in order to compare the groups that received the complement or not, and Student's t-test, in order to deal with quantitative variables with normal distribution. The joint effect of the association of variables was assessed by means of Poisson's Regression. Initially, independent variables with $\mathrm{p}$ value $\leq$ 0.20 were eligible in Pearson's Chi-Square; and, in the next block, the permanence of variables with $p$ value < 0.10 . In the final model, the explanatory variables with $p$ value $\leq 0.05$ and $95 \%$ confidence interval were considered, which met the assumptions established for the adjustment (Goodness off fit), significance (Omnibus Test) and dispersion.

\section{Ethics}

The ethical approval was granted by the Research Ethics Committee from the Onofre Lopes University Hospital, under opinion $n^{\circ} 3.133217$, being in line with Resolution $n^{\circ} 466 / 2012$, which contemplates guidelines and regulatory norms for research with human beings. After the selection step, the women who attended the inclusion criteria were consulted about the interest in participating in this research. When it was accepted, the Free and Informed Consent Form was applied. If the participant was under 18 years old, the consent was obtained from parents or guardian on behalf.

\section{Results}

\section{Institutional and participants' characteristics}

Of the 415 mother/child binomials, 213 (51.3\%) of NB received complements. Table 1 shows the distribution of complement utilization based on variables that characterize the institutions. Similar results are observed in both groups, without statistically significant difference $(p>0.05)$ when the administrative nature, the level of complexity, the BFHI degree and the ratio of the number of professionals per bed are assessed. Table 2 shows the welfare, maternal and neonatal characteristics. There was a predominance of mothers aged between 20 and 29 years (46.5\%), where more than $60 \%$ had a high school degree, they were married or living in a stable union and multiparous, with income less than or equal to 1 minimum wage. With regard to NB, $52.5 \%$ were male and $90.4 \%$ were born with weight between 2,500 and 4,000 grams.

\section{Characteristics of the offer of complements}

Of the 213 (51.3\%) of NB that received complements, 57.6\% was in the first hour of life and, on average, 5.6 \pm 7.2 hours after birth. As for the type of complement offered, $92 \%$ had infant formula. Of the total of NB that received the complement, $29.9 \%$ had no medical prescription. The main reason described in the medical record or informed by the mother was the absence or deficiency of colostrum (33.8\%), while $23.9 \%$ had no reason for indication (Table 3).

\section{Factors associated with the offer of food complements}


The maternal characteristics initially revealed a significant association $(p \leq 0.05)$ for the offer of the maternal milk complement. Even after multiple analysis, the outcome remained significantly associated with the variables related to age, parity and type of delivery. When it was analyze each explanatory variable individually, maternal age $\leq 20$ years showed a protective effect in $36 \%$ and age between 20 and 29 years old protective effect of $30 \%$. When it was considered only the predictive factors, the prevalence increases $1.37(\mathrm{Cl}=1.11-1.60)$ and $1.20(\mathrm{Cl}=1.00-1.45)$ times, respectively for primiparity and cesarean delivery (Table 2).

\section{Discussion}

In this study, we found a high prevalence of complement offer, which corroborates the findings of studies conducted in other countries and in Brazilian cities $[2,14,15,19]$. Although the WHO recommends skin-toskin contact at birth, breastfeeding in the first hour of life and "Do not give the newborn baby any food or drink other than breast milk, unless such procedure has a medical indication", most NB received the complement in the first hours and days after birth. We even found that this offer happened without any justifiable indication on the part of BFHI and often without a medical prescription.

The actions instituted by the United Nations Children's Fund and the WHO, through BFHI, have contributed to the success of breastfeeding and to the reduction of the offer of complementary food $[4,20]$, which differs from the results introduced in this research. Among the participating institutions, only one did not have the degree named "Baby-Friendly Hospital Initiative". Nevertheless, holding this degree did not favor the achievement of differentiated outcomes. The administrative nature, the level of complexity and the ratio of the number of professionals per bed did not influence the offer of the complement. These findings differ from those obtained by studies in the United Kingdom, whose lack of personnel, perception of the importance of support and professional education were associated with the offer of the complement with infant formulas [12]. However, sociocultural and biological maternal factors were protective (age) and predictors (parity and type of delivery) for such an outcome.

The maternal age under 29 years behaved as a protective factor, opposing the Australian study developed by Bentley and collaborators [17]. This study had the participation of mothers whose intention was to exclusively breastfeed. However, NB whose mothers were less than 25 years old had $20 \%$ more indication of maternal milk complement than those with higher ages. The protective effect identified in this study may be due to the priority care recommended by the WHO for this most vulnerable group.

Conversely, the prevalence of this offer increased by 1.37 times for NB of primiparous mothers, being consistent with the pertinent literature. This vulnerability can be justified by the absence of previous breastfeeding [16, 21], inadequate milk perception, pain, breast milk problems [22] and cesarean section. The latter was associated to a $20 \%$ increase in the complement prevalence, corroborating the findings in the pertinent literature [17]. When knowing that $46 \%$ of the children in this study were born from cesarean section - being even higher than the recommended by the WHO $(10 \%)$ to reduce maternal and neonatal mortality - such association is worrying. Brazil has implemented public policies that, in addition to contributing to the reduction of unnecessary interventions to the mother-child binomial, also aim at 
improving breastfeeding indicators from their promotion. Among them, we can highlight the Stork Network, the Apice-On qualification and the BFHI [1, 23].

Nonetheless, the main reason for indicating the complement was the absence of colostrum; however, this does not fit as an acceptable medical reason. Conversely, only $42.3 \%$ showed clinical conditions justifiable through BFHI (deficiency of latch and suction, large NB for gestational age, among other reasons related to the clinical conditions of NB and mothers) [4].

Besides these, the absence of records about the reasons in the medical records and the absence of explanation about the offer of the complement to the mother encompassed $24 \%$ of the sample. Such findings are in agreement with the study by Newhook et al. [10]; and in disagreement with those of Pinheiro et al. (2016) [6], also conducted in Rio Grande do Norte - the same state where the present study happened - as well as in the study by Biggs et al. [12] in the United Kingdom.

No matter how strictly the indication criteria are defined, in order to maintain NB in EB, the occurrence of hypoglycemia is a constant concern of the health care team. The maternal desire in offering the complement has been another reason that has led the health team to adopt such behavior [24]. In order for the mother to be able to go through this process without the newborn needing the use of a complement, we should underline the essentiality of the support of the multiprofessional team - who must be engaged and follow the guidelines of the "Ten Steps to Successful Breastfeeding" - in the delivery room and in the rooming-in setting. Breastfeeding in the first hour of life, as well as guidance on breastfeeding techniques and the characteristics and benefits of breastfeeding, allow maternal empowerment and are fundamental to reassure the mother. Accordingly, emotional balance is achieved, lactogenesis is favored, baby sucking is successful and breastfeeding becomes mutually beneficial: for the child and his/her nursing mother, thus strengthening the mother-child bond.

The absence of colostrum or hypogalactia - reported in the pertinent literature as the main reason for early weaning - consists in the reduction of milk secretion. It is caused by hormonal changes in oxytocin and prolactin levels, a condition often associated with biological, psychosocial and behavioral factors. Among them, we can mention the first delivery, the surgical procedure, the pain, the discomfort, the anxiety, the stress and the prematurity. Such situations can delay the hormonal release and the first support (which usually happens within 72 hours after delivery) and, consequently, favor the maternal desire for the complement $[6,25,26]$. Late lactogenesis may also be due to inadequate latch, lack of suction and formula offer in the first hours of life [27,28]. Nevertheless, it is necessary to hold a careful assessment in such a way as to consider the type of delivery and parity, since, in a study performed by Isik and collaborators [29], there was no statistically significant correlation regarding the production of prolactin and these factors. Moreover, we should underline that, although the absence of colostrum is not justifiable, if such condition is prolonged, the risk of hypoglycemia is eminent, especially in premature NB and gestational age [14, 17]. Glycemia was one of the studied variables, but a limitation of its use was to have been collected in only 3 maternity wards. For this reason, we chose not to include it in the final model. However, it is important to point out that only one third of NB that received the complement had glycemic records. 
When considering that hypoglycemia is a concern of the health team and is among the conditions where the complement is prescribed, this study found that such offer happened without this assessment in most cases. Then, we observed a significant association of indication when the glycemia was between 40$50 \mathrm{mg} / \mathrm{dL}$ - although there was also a high quantitative of NB that received complement when the glycemia was higher. There is still no consensus in the pertinent literature about the offer of formulas to reduce cases of hypoglycemia in NB, nor the definition of glycemic values that characterizes it and, therefore, supports the indication of complements. The dialogue with the team revealed interprofessional and institutional differences in the standardization of these values. Accordingly, such definition is still at the discretion of clinical assessment, according to the individuality of each child [30].

In healthy conditions, parturient women have biological conditions that are sufficiently favorable for breast milk production in the first hours after birth. However, mother's and health team's perception of "insufficient milk" is still frequent. This leads to the lack of adequate waiting and/or stimulation for colostrum dripping - including the absence of skin-to-skin contact and breastfeeding in the first hour of life of NB. In this study, the complement was offered, on average, 5.6 hours after birth, being this time lower than the reported in the pertinent literature (8.7 hours). Nevertheless, this may be a harmful factor to EB after discharge [19.21]. The time of the offer is highlighted in the pertinent literature and justified by the longer period of professional activity and maternal tiredness for the day shift, which may undermine exclusive breastfeeding after discharge [6, 21].

Another much discussed point is the type of complement offered. Despite the unanimity in offering $\mathrm{BM}$, the maternity wards that have a milk bank - two of the institutions participating in this study - do not have sufficient stock for the full-term NB, thus prioritizing, for them, the offer of starting infant formulas. The pertinent literature warns that artificial formulas are associated to the risk of allergies and changes of the intestinal microbiota. A control case study reported a 16 times higher probability in the development of allergy to cow's milk protein when NB received a complement to the maternal milk with artificial milk formula in the first 24 hours of life [14]. Other studies identified dysbiosis, with lower quantities of Bifidobacteria and higher quantities of Enterobacteria, being this a condition that was also associated to NB born from cesarean section $[18,31]$.

The quantity of the complement offered may also interfere with breastfeeding. In this study, more than $80 \%$ of NB received it in quantity less than or equal to $10 \mathrm{~mL}$, which corresponds to the approximate volume of colostrum produced in each feeding in the first week of life. The pertinent literature points out complement volumes higher than those of the present research, initially varying from 30 to $57 \mathrm{~mL}$, progressing to about $100 \mathrm{~mL}$ on the fourth day and reducing to, on average, $26 \mathrm{~mL}$ in the period of discharge $[6,19]$.

Policies to combat advertising and discounts of infant formulas from the pharmaceutical industry to hospitals may be viable alternatives to decrease the offer of complements in these environments. As an example, there is a hospital in Hong Kong, where the offer of formula complements was reduced by $57 \%$, the EB rate was increased by $23.6 \%$ during hospitalization and the breastfeeding time was increased from 8 to 12 weeks [32]. In Brazil, this practice was instituted by the Brazilian Standard for Commercialization of Food for Infants, Young Children, Nipples, Pacifiers and Bottles (NBCAL - Law 11.265/2006) [9], but the 
effect on the use of formulas to replace breast milk in hospitals is still unknown. Strategies such as the milk donation campaign are fundamental to increase stocks in HMB and, therefore, promote breastfeeding.

Among the limitations of this study, we should mention the non-totality of the sample of some of the explanatory variables for the complement offer - such as the time of its offer and the capillary glycemia. Although it has been held in only one city, the results of this research are consistent with the pertinent literature. At the same time, such findings are strengthened by the previous accomplishment of a pilot study for better applicability of the research instrument and by the collection of information having been performed when NB were exposed to the use of the complement. Accordingly, memory biases were minimized and the confirmation and validation of the information entered in the medical records was allowed.

\section{Conclusion}

The results of this study have confirmed that maternal characteristics are determinant for the offer of the complement to NB, as well as the indispensability of protection to the most vulnerable mothers. In view of the findings, the present study favors the addition of knowledge about the predictors to the offer of the complement, reinforcing the need for a careful clinical assessment and verification of capillary glycemia as tools to support its proper prescription, besides the need for investigations about the contribution of the use of complements to the occurrence of early weaning in these children. Moreover, when considering the role of the health care team in promoting breastfeeding, the findings of this research strengthen the team's awareness, as well as the planning and implementation of educational actions necessary for the empowerment of mothers about the mutual benefit of breast milk for the binomial. Such understanding is paramount for the development of interventions that minimize the inadequate offer of the complement and promote EB. However, surveys focusing on work processes and maternal desire regarding breastfeeding are still scarce in literature. Accordingly, studies with this focus are necessary to ensure the promotion of breastfeeding on spontaneous demand.

\section{Abbreviations}

EB: exclusive breastfeeding

BF: breastfeeding

NB: newborn

BFHI: Baby-Friendly Hospital Initiative

HMB: Human Milk Banks

SUS: Unified Health System

PNAISC: National Policy for Comprehensive Child Health Care 
WHO: World Health Organization

NBCAL: Brazilian Standard for Commercialization of Food for Infants, Young Children, Nipples, Pacifiers and Bottles.

\section{Declarations}

\section{Ethics approval and consent to participate}

The ethical approval was granted by the Research Ethics Committee from the Onofre Lopes University Hospital, under opinion $n^{\circ} 3.133217$, being in line with Resolution $n^{\circ} 466 / 2012$, which contemplates guidelines and regulatory norms for research with human beings. After the selection step, the women who attended the inclusion criteria were consulted about the interest in participating in this research. When it was accepted, the Free and Informed Consent Form was applied. If the participant was under 18 years old, the consent was obtained from parents or guardian on behalf.

\section{Consent for publication}

Not applicable.

\section{Availability of data and materials}

The datasets used and/or analyzed during the current study are available from the corresponding author on reasonable request.

\section{Competing interests}

The authors declare that they have no competing interests.

\section{Funding}

None.

\section{Authors' contributions}

JMFP, TBMF, FBA took part in the conception, study design and statistical analysis. JMFP, TBMF, AMBM reviewed and edited the manuscript. VCCP, LICO, WPMB contributed to the collection of research data. All authors have read and approved the final version and are responsible for the final content of this manuscript.

\section{Acknowledgements}

We thank the mothers and the maternity wards who/which collaborated with the study.

\section{References}


1. World Health Organization. Guideline: protecting, promoting and supporting breastfeeding in facilities providing maternity and newborn services. Geneva: WHO, 2017.

2. Silva OLO, Rea MF, Venâncio SI, Buccini GS. A Iniciativa Hospital Amigo da Criança: contribuição para o incremento da amamentação e a redução da mortalidade infantil no Brasil. Rev Bras Saude Mater Infant. 2018; 18(3): 491-99. https://doi.org/10.1590/1806-93042018000300003.

3. Victora CG, Bahl R, Barros AJD, França GVA, Horton S, Krasevec J, Murch S, Sankar MJ, Walker N, Rollins NC. Breastfeeding in the 21st century: epidemiology, mechanisms, and lifelong effect. Lancet. 2016; 387(10017):475-90. https://doi.org/10.1016/S0140-6736(15)01024-7.

4. Fundo das Nações Unidas para a Infância (UNICEF). Iniciativa Hospital Amigo da Criança: revista, atualizada e ampliada para o cuidado integrado: módulo 1: histórico e implementação. UNICEF. Brasília: Ministério da Saúde, 2008.

5. Saco MC, Coca KP, Marcacine KO, Abuchaim ESV, Abrão ACFV. Contato pele a pele e mamada precoce: fatores associados e influência no aleitamento materno exclusivo. Texto \& contexto enfermagem. 2019; 28:e20180260. https://doi.org/10.1590/1980-265x-tce-2018-0260.

6. Pinheiro JMP, Menêzes TB, Brito KMF, Melo ANL, Queiroz DJM, Sureira TM. Prevalência e fatores associados à prescrição/solicitação de suplementação alimentar em recém-nascidos. Rev Nutr. 2016; 29(3):367-75. http://doi.org/10.1590/1678-98652016000300007.

7. Da Silva JLP, Linhares FMP, Barros, AA, Souza AG, Alves DS, Andrade PON. FATORES ASSOCIADOS AO ALEITAMENTO MATERNO NA PRIMEIRA HORA DE VIDA EM UM HOSPITAL AMIGO DA CRIANÇA. Texto \& contexto enfermagem. 2018; 27(4):e4190017. https://doi.org/10.1590/0104-07072018004190017.

8. Ministerio da Saude. Secretaria de Atencão à Saude. Departamento de Ações Programáticas Estratégicas. Bases para a discussão da política nacional de promoção, protecão e apoio ao aleitamento materno. Brasília (DF): Ministério da Saude; 2017.

9. Brasil - Presidência da República. Lei n 11.265, de 3 de janeiro de 2006. Regulamenta a comercialização de alimentos para lactentes e crianças de primeira infância e também a de produtos de puericultura correlatos. Brasília: Diário Oficial da União; 2006.

10. Newhook JT, Newhook LH, Midodzi WK, Goodridge JM, Burrage L, Gill N, Halfyard B, Twells L. Determinants of Nonmedically Indicated In-Hospital Supplementation of Infants Whose Birthing Parents Intended to Exclusively Breastfeed. J Hum Lacta. 2017;33(2): 278-84. https://doi.org/10.1590/s1980-220x2018034303564.

11. Khanal V, Scott JÁ, Lee AH, Karkee R, Binn CW. The supplemental use of infant formula in the context of universal breastfeeding practices in Western Nepal. BMC Pediatr. 2016;16(68):1-7. https://doi.org/10.1186/s12887-016-0602-1.

12. Biggs KV, Hurrell E, Khaleva E. Munblit D, Boyle RJ. Formula Milk Supplementation on the Postnatal Ward: A Cross-Sectional Analytical Study. Nutrients. 2018; 10(5):608. https://doi.org/10.1590/s1980$220 \times 2018034303564$.

13. Zarshenas M, Zhao Y, Binns CW, Scott JA. Determinants of in-hospital feeding practices in Shiraz, Iran: Results of a prospective cohort study. Birth. 2018; 46(1):137-45. https://doi.org/10.1590/s1980$220 \times 2018034303564$. 
14. Kelly E, DunnGalvin G, Murphy BP, Hourihane JO’B. Formula supplementation remains a risk for cow's milk allergy. Pediatr Allergy Immunol. 2019; 30(8):810-16. https://doi.org/10.1590/s1980$220 \times 2018034303564$.

15. Pierro J, Abulaimoun Bdair, Roth P, Blau J. Factors Associated with Supplemental Formula Feeding of Breastfeeding Infants During Postpartum. Breastfeed Med. 2016; 11(4):196-202. https://doi.org/10.1590/s1980-220x2018034303564.

16. Carreiro JA, Francisco AA, Abrão AC, Marcacine KO, Abuchaim ES, Coca KP. Dificuldades relacionadas ao aleitamento materno: análise de um serviço especializado em amamentação. Acta Paul Enferm. 2018;31(4):430-8. https://doi.org/10.1590/s1980-220x2018034303564.

17. Bentley JP, Nassar N, Porter M, de Vroome M, Yip E, Ampt AJ. Formula supplementation in hospital and subsequent feeding at discharge among women who intended to exclusively breastfeed: An administrative data retrospective cohort study. Birth. 2017;44(4):352-62. https://doi.org/10.1590/s1980-220x2018034303564.

18. Forbes JD, Azad MB, Vehling L, Tun HM, Konya T, Guttman DS, et al. Association of Exposure to Formula in the Hospital and Subsequent Infant Feeding Practices With Gut Microbiota and Risk of Overweight in the First Year of Life. JAMA Pediatr. 2018;172(7):704]. https://doi.org/10.1590/0102$311 \times 00063818$.

19. Cordero L, Stenger MR, Landon MB, Nankervis CA. In-hospital formula supplementation and breastfeeding initiation in infants born to women with pregestational diabetes mellitus. J Neonatal Perinatal Med. 2019;12(3):285-93. https://doi.org/10.1590/1980-265x-tce-2018-0260.

20. Lamouniera JA, Chaves RG, Rego MAS, Bouzadac MCF. Iniciativa hospital amigo da criança: 25 anos de experiência no Brasil. Rev Paul Pediatr. 2019;37(4):486-93. https://doi.org/10.1590/19840462/;2019;37;4;00004.

21. Garrison MP, Maisano P. Systematic Review of Factors Influencing Non-Medically Indicated Formula Supplementation of Newborns in the Hospital Setting. Nurs Womens Health. 2019;23(4):340-50. https://doi.org/10.1590/1984-0462/;2019;37;4;00004.

22. Demirci JR, Bogen DL. An Ecological Momentary Assessment of Primiparous Women's Breastfeeding Behavior and Problems From Birth to 8 Weeks. J Hum Lact. 2017;33(2):285-95. https://doi.org/10.1590/1984-0462/;2019;37;4;00004.

23. Leal MC; Parto e nascimento no Brasil: um cenário em processo de mudança. Cad Saude Publica. 2018;34(5):e00063818. https://doi.org/10.1590/0102-311x00063818.

24. Kair LR, Flaherman VJ. Donor Milk or Formula: A Qualitative Studdy of Postpartum Mothers of Healthy Newborn. J Hum Lact. 2017;33(4):710-16. https://doi.org/10.1590/0102-311x00063818.

25. Dimitraki M, Tsikouras P, Manav B, Gioka T, Koutlaki N, Zervoudis S, et al. Evaluation of the effect of natural and emotional stress of labor on lactation and breast-feeding. Arch Gynecol Obstet. 2016;293(2):317-28. https://doi.org/10.1590/0102-311x00063818.

26. Ministério da Saúde. Atenção à saúde do recém-nascido: guia para os profissionais de saúde. Volume 1. Série A. Normas e Manuais Técnicos. Brasília: Ministério da Saúde; 2011. 
27. Gasparin VA, Strada JKR, Moraes BA, Betti T, Gonçalves AC, Santo LCDE. Pairs seen by lactation consultants and cessation of exclusive breastfeeding in the first month. Rev Esc Enferm USP. 2019;53:e03422. https://doi.org/10.1590/0102-311x00063818.

28. Rocha BO. Hipogalactia inicial, fatores de risco para o desmame precoce e promoção do aleitamento materno em primíparas atendidas em um hospital amigo da criança no brasil. [dissertação]. Universidade Federal de Minas Gerais; 2018.

29. İsik Y, Dag ZO, Tulmac OB, Pek E. Early postpartum lactation effects of cesarean and vaginal birth. Ginekol Pol. 2016;87(6):426-30. https://doi.org/10.1590/0102-311x00063818.

30. Rozance PJ, Wolfsdorf Jl. Hypoglycemia in the Newborn. Pediatr Clin North Am. 2019;66(2):333-42. https://doi.org/10.1590/0102-311x00063818.

31. Madan JC, Hoen AG, Lundgrenc SN, Farzan SF, Cottingham KL, Morrison HG, Sogin ML, et al. Effects of Cesarean delivery and formula supplementation on the intestinal microbiome of six-week old infants. JAMA Pediatr. 2016;170(3): 212-19. https://doi.org/10.1590/0102-311x00063818.

32. Tarrant M, Lok KY, Fong DY, Lee IL, Sham A, Lam C, Wu KM, Bai DL, Wong KL, Wong EM, Chan NP, Dodgson JE. Effect of a hospital policy of not accepting free infant formula on in-hospital formula supplementation rates and breast-feeding duration. Public Health Nutr. 2015;18(14):2689-99. https://doi.org/10.1590/0102-311x00063818.

\section{Tables}

Table 1: Institutional characteristics of the study setting. Natal/Brazil, 2019. 


\begin{tabular}{|c|c|c|c|}
\hline \multirow[t]{2}{*}{ Variables } & \multicolumn{3}{|c|}{ Food complement offer $(n=213)$} \\
\hline & $\mathrm{n}(\%)$ & $\mathrm{Cl}(95 \%)$ & $p$ value \\
\hline \multicolumn{4}{|l|}{ Administrative nature of the maternity ward } \\
\hline Municipal & $91(42.7)$ & $36.1-49.4$ & 0.382 \\
\hline State & $54(25.3)$ & $19.5-31.2$ & \\
\hline Federal & $68(31.9)$ & 25.7-38.2 & \\
\hline \multicolumn{4}{|l|}{ Level of complexity } \\
\hline Low risk & 91 (42.7) & $36,1-49,4$ & 0.199 \\
\hline High risk & $122(57.3)$ & $51,0-63,9$ & \\
\hline \multicolumn{4}{|l|}{ BFHI degree } \\
\hline Yes & $161(75.6)$ & $70.0-81.4$ & 0.936 \\
\hline \multirow[t]{2}{*}{ No } & $52(24.4)$ & $18.6-30.2$ & \\
\hline & \multicolumn{2}{|c|}{ Average (SD) } & $p$ value \\
\hline Ratio of the number of professionals per bed & $1.25(0,04)$ & & $0.971^{\mathrm{a}}$ \\
\hline Ratio of the number of pediatricians per bed & $0.13(0,02)$ & & $0.875^{a}$ \\
\hline
\end{tabular}

BFHI: Baby-Friendly Hospital Initiative. SD: standard deviation. Cl: confidence interval.

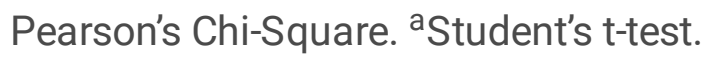

Table 2: Multivariate analysis of maternal, newborn and health care characteristics conditioning the offer of food complements. Natal/Brazil, 2019. 
Variables

79

193

143

$>30$ years

\section{Education}

High school to higher

$271 \quad 146$

53.9

0.154

Elementary School

$\begin{array}{lllll}\begin{array}{l}\text { Maternal characteristics } \\ \text { Maternal age }\end{array} & & & & \\ \leq 20 \text { years } & 79 & 37 & 46.8 & 0.019 \\ 20 \text { to } 29 \text { years } & 193 & 89 & 46.1 & \\ >30 \text { years } & 143 & 87 & 60.8 & \\ & & & & \\ \text { Education } & & & & \\ \text { High school to higher } & 271 & 146 & 53.9 & 0.154 \\ \text { Elementary School } & 144 & 67 & 46.5 & \end{array}$

67

46.5

Marital status

Married or stable union

Single/divorced/widowed

328

87

Income

$>1$ minimum wage

147

268

$\leq 1$ minimum wage

Gestational diabetes

Yes

No

Parity

Multiparous

261

Primiparous

154

126

48.3

0.11

$87 \quad 56.5$
Not adjusted

PR
Adjusted

CI (95\%)
PR $\quad \mathrm{Cl}(95 \%)$ $p$ 


\begin{tabular}{|c|c|c|c|c|c|c|c|c|c|}
\hline For up to 6 months & 83 & 43 & 50.0 & 0.945 & - & - & - & - & - \\
\hline 7 to 12 months & 70 & 35 & 50.0 & & & & & & \\
\hline $\begin{array}{l}\text { For more than } 12 \\
\text { months }\end{array}$ & 123 & 64 & 52.0 & & & & & & \\
\hline \multicolumn{10}{|l|}{ Characteristics of NB } \\
\hline \multicolumn{10}{|l|}{ Child's gender } \\
\hline Male & 218 & 117 & 53.7 & 0.182 & - & - & - & - & - \\
\hline Female & 197 & 96 & 48.7 & & & & & & \\
\hline \multicolumn{10}{|l|}{ Birth weight ${ }^{b}$} \\
\hline $2,500-4,000 \mathrm{~g}$ & 375 & 189 & 50.4 & 0.098 & 1 & - & - & - & - \\
\hline$>4,000 \mathrm{~g}$ & 32 & 21 & 65.6 & & 1.32 & $\begin{array}{l}0.99- \\
1.71\end{array}$ & - & - & - \\
\hline \multicolumn{10}{|l|}{$\begin{array}{l}\text { Pre-supplemental } \\
\text { glycemiac }^{c}\end{array}$} \\
\hline$<40 \mathrm{mg} / \mathrm{dL}$ & 36 & 31 & 86.1 & & & & & & \\
\hline $\begin{array}{l}40-50 \mathrm{mg} / \mathrm{dL} \\
>50 \mathrm{mg} / \mathrm{dL}\end{array}$ & 32 & 21 & 65.6 & & & & & & \\
\hline \multicolumn{10}{|l|}{$\begin{array}{l}\text { Health care } \\
\text { characteristics }\end{array}$} \\
\hline $\begin{array}{l}\text { Companion during } \\
\text { delivery }\end{array}$ & 307 & 151 & 49.2 & 0.087 & 1 & - & - & - & $\begin{array}{ll}- & \text { r }\end{array}$ \\
\hline Yes & 108 & 62 & 57.4 & & 1.17 & $\begin{array}{l}0.96- \\
1.42\end{array}$ & - & - & - \\
\hline No & & & & & & & & & \\
\hline \multicolumn{10}{|l|}{ Skin-to-skin contact } \\
\hline Yes & 246 & 124 & 50.4 & 0.651 & - & - & - & - & - \\
\hline No & 169 & 89 & 52.7 & & & & & & \\
\hline \multicolumn{10}{|c|}{$\begin{array}{l}\text { Breastfeeding in the first } \\
\text { hour of life }\end{array}$} \\
\hline Yes & 242 & 114 & 47.1 & 0.036 & 1 & - & - & - & $\begin{array}{ll}- & \text { r }\end{array}$ \\
\hline No & 172 & 99 & 57.6 & & 1.22 & $\begin{array}{l}1.01- \\
1.47\end{array}$ & - & - & $\begin{array}{ll}- & \text { r }\end{array}$ \\
\hline
\end{tabular}

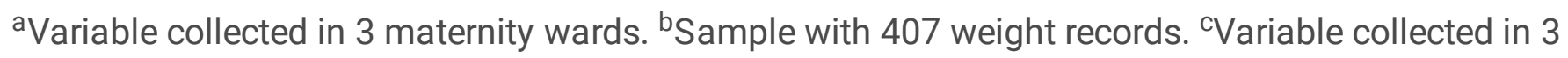
maternity wards ( $n=296 / 415$ (23.4\%), and not included in the Regression model.

NB: newborn. BF: breastfeeding. PN: Prenatal care. BM: breast milk. g: grams. Mg/dL: milligrams/deciliters. 
Poisson's regression. PR: prevalence ratio. Cl: confidence interval. Significant $p \leq 0.05$.

Table 3: Reasons for indication and characteristics of the food complement offered to NB. Natal/Brazil, 2019. $(n=213)$.

\begin{tabular}{|c|c|c|}
\hline Variables & $\mathrm{n}(\%)$ & $\mathrm{Cl}(95 \%)$ \\
\hline \multicolumn{3}{|l|}{ Reason for offering complements to NB } \\
\hline Colostrum deficiency & $72(33.8)$ & $27.5-40.2$ \\
\hline Difficulty in latching/sucking & $50(23.5)$ & $17.8-29.2$ \\
\hline LGA & $7(3.3)$ & $0.9-5.7$ \\
\hline Other problems related to NB & $18(8.5)$ & $4.7-12.2$ \\
\hline Other maternal problems & $15(7.0)$ & $3.6-10.5$ \\
\hline Without prescribed reasons & $51(23.9)$ & 18.2-29.7 \\
\hline \multicolumn{3}{|l|}{ Medical prescription of the complement } \\
\hline Yes & $108(50.7)$ & $44.0-57.4$ \\
\hline No & $105(49.3)$ & $42.6-56.0$ \\
\hline \multicolumn{3}{|l|}{ Time of the complement offer to NB $(n=148)^{a}$} \\
\hline Morning (6:00 a.m. to 6:00 p.m.) & $76(35.7)$ & $29.0-42.0$ \\
\hline Night (6:00 p.m. to 6:00 a.m.) & $72(37.8)$ & $27.0-40.0$ \\
\hline \multicolumn{3}{|l|}{ Type of complement } \\
\hline Pasteurized breast milk & $17(8.0)$ & $43.3-59.4$ \\
\hline Infant formula & $196(92.0)$ & $40.6-56.7$ \\
\hline \multicolumn{3}{|l|}{ Complement volume offered } \\
\hline$\leq 10 \mathrm{ml}$ & $174(81.7)$ & $76.5-86.9$ \\
\hline \multirow[t]{2}{*}{$>10 \mathrm{ml}$} & $39(18.3)$ & $13.1-23.5$ \\
\hline & \multicolumn{2}{|c|}{ Average (SD) } \\
\hline Beginning of the supplement offer after the birth of NB (hours) & $5.61(7.2)$ & \\
\hline
\end{tabular}

${ }^{a}$ Time records of only 148 newborns who received complements. NB: newborn. SD: standard deviation. GIG: large for gestational age. 